\title{
PROGRAM KEMITRAAN MASYARAKAT (PKM) PENINGKATAN KEMAMPUAN APARATUR KELURAHAN DI KELURAHAN MATANI DUA KOTA TOMOHON
}

\author{
Mariam Wullur \\ Universitas Negeri Manado \\ mariamwullur@unima.ac.id
}

\begin{abstract}
Abstrak
Adapun tujuan dari kegiatan pengabdian ini adalah memberdayakan dan meningkatkan keterampilan aparatur dan masyarakat desa tentang administrasi pemerintahan desa, meningkatkan pengetahuan aparatur dan masyarakat desa dengan fokus pada laporan keuangan desa, dan mendorong tertib administrasi pelayanan desa. Pengabdian ini bertempat di Kelurahan Matani Dua Kota Tomohon dengan menggunakan metode penyuluhan, pelatihan dan pendampingan, uji coba, monitoring dan evaluasim sehingga ditemukan bahwa Aparatur Pemerintahan Desa dan masyarakat Kelurahan Matani Dua Kota Tomohon sebagai mitra pengabdian masyarakat memiliki respon dan antusias yang sangat besar terutama dalam proses pelatihan walaupun dengan segala keterbatasan yang dimiliki dan melalui kegiatan pelatihan administrasi pemerintahan desa kelurahan dan laporan keuangan berjalan sesuai dengan rencana dan target yang telah ditetapkan.
\end{abstract}

Kata kunci: Pembinaan, Kapasitas, Aparatur, Administrasi.

\section{PENDAHULUAN}

\section{Analisis Situasi}

Tertibnya penyelenggaraan pemerintahan desa setidaknya harus didukung dan dipayungi oleh peraturan desa yang disusun bersama pemerintah desa dan BPD. Demikian pula dengan pelaksanaan program pemerintahan, pembangunan, pembinaan dan pemberdayaan masyarakat yang tertata dalam Anggaran Pendapatan dan Belanja Desa (APBDesa).

Anggaran Pendapatan dan Belanja Desa adalah rencana keuangan desa dalam satu tahun yang memuat perkiraan pendapatan, rencana belanja program dan kegiatan, di mana rencana pembiayaan dibahas dan disetujui bersama oleh pemerintah desa dan badan permusyawaratan desa, yang ditetapkan dalam peraturan desa. Penyelenggaraan pemerintahan desa yang output-nya berupa pelayanan publik, pembangunan dan perlindungan masyarakat harus disusun perencanaannya setiap tahun dan dituangkan dalam APBDesa. Dalam APBDesa inilah terlihat apa yang akan dikerjakan oleh pemerintah desa dalam tahun berjalan, sehingga dipastikan dapat dilaksanakan.

Pemerintahan desa sebagai bagian dari sistem sosial memiliki peran yang sangat penting dalam pengelolaan modal sosial yang dimiliki oleh masyarakat [1]. Modal sosial masyarakat berupa nilai-nilai tradisional, kearifan lokal, sosial dan budaya dan kehidupan gotong royong merupakan kohesi masyarakat dalam menghadapi 
permasalahan di tengah perubahan dan dinamika global. Meskipun demikian kekuatan modal sosial tersebut perlu didukung dengan penyelenggaraan administrasi pemerintahan desa dan laporan keuangan desa yang tertib dalam rangka pelaksanaan pembangunan, pembinaan kemasyarakatan dan pemberdayaan masyarakat.

Dalam melaksanakan penyelenggaraan administrasi pemerintahan desa dan laporan keuangan desa yang tertib tersebut diperlukan aparatur pemerintahan desa dan masyarakat yang mampu dan memiliki kapasitas. Berdasarkan hasil analisis situasi sosial ditemukan permasalahan masih rendahnya kemampuan aparatur pemerintahan desa dalam pengelolaan penyusunan kebijakan desa dan manajemen pelayanan desa dan minimnya kemampuan tenaga pengelola keuangan desa sehingga menghambat penyusunan perencanaan keuangan. Dalam hal ini, keberadaaan pendamping desa sebagai tenaga fasilitator masih belum dapat memberikan daya dukung terhadap peningkatan kapasitas aparatur pemerintahan dan masyarakat. Salah satu diantaranya dikarenakan terlalu luasnya wilayah kerja pendamping desa yaitu lebih dari 2 (dua) desa dimana idealnya adalah 1 (satu) desa 1 (satu) pendamping desa.

Dalam konteks penyelenggaraan pemerintahan daerah yang terpenting adalah bagaimana pemerintahan desa mampu meningkatkan kesejahteraan rakyatnya, mampu memberikan pelayanan kepada masyarakat desa, dan mampu meningkatkan daya saing desanya [2]. Oleh sebab itu, peningkatan kapasitas aparatur desa dalam tata kelola administrasi pemerintahan desa menjadi hal yang sangat penting. Dalam hal ini, upaya bagi aparatur pemerintahan desa untuk mengikuti pelatihan administrasi pemerintahan desa perlu dilakukan

Tugas dan tanggung jawab pemerintahan desa adalah menyelenggarakan musrenbang sebagai forum musyawarah perencanaan pembangunan desa dan menyusun Rencana Pembangunan Jangka Menengah Desa (RPJMDesa) dan Rencana Kerja Pemerintahan Desa (RKPDes). Akan tetapi, pada pelaksanaannya musrenbang belum dilakukan berdasarkan prinsip-prinsip perencanaan dan kebutuhan dasar masyarakat desa dan hanya terfokus pada pembangunan infrastruktur jalan. Artinya, masyarakat belum diberikan ruang untuk menyuarakan aspirasinya karena berbagai alasan seperti kepercayaan yang terlalu besar terhadap kepala desa dan besarnya pengaruh dan dominasi aparatur desa. Meskipun musyawarah perencanaan pembangunan desa (musrembangdes) sudah dilaksanakan akan tetapi masih terdapat berbagai permasalahan terkait dengan aspek pengambilan keputusan perencanaan pembangunan desa yang masih bersifat sentralistik dimana masih 
besarnya pengaruh kepala desa dan aparat desa dalam pengambilan keputusan [1].

Dengan melihat berbagai permasalahan desa baik dari aspek administrasi pemerintahan maupun tata kelola keuangan terutama dalam meningkatkan kapasitas aparatur pemerintahan desa dalam mewujudkan tertib administrasi yang mampu berfungsi sebagai sumber data dan informasi dalam penyelenggaraan pemerintahan, pelaksanaan pembangunan, pembinaan kemasyarakatan dan pemberdayaan masyarakat, maka solusi yang ditawarkan adalah mengadakan kegiatan pengabdian masyarakat melalui pelatihan administrasi pemerintahan desa dan tata kelola keuangan desa yang dilakukan oleh tim pengabdian masyarakat bekerjasama dengan aparatur desa dan masyarakat Kelurahan Matani Dua Kota Tomohon.

Sedikitnya terdapat 3 (tiga) hal utama dalam melakukan pengelolaan atau penyelenggaraan pemerintahan/ birokrasi yang efektif dan efisien yaitu melakukan suatu langkah, upaya, ataukah perlakuan yang optimal dan merujuk kepada prinsipprinsip tata kelola pemerintahan yang baik (good governance) terhadap kelembagaan (organisasi), ketatalaksanaan (business process), dan yang paling utama adalah sumberdaya manusia aparatur. Oleh karenanya, program reformasi birokrasi yang saat ini tengah gencar dilakukan, harus melibatkan atau mendasarkan prosesnya pada ketiga komponen utama tersebut diatas disamping faktor-faktor pendukung lainnya.

PER/ 15/ M.PAN/ 7/ 2008 Tentang Pedoman Umum Reformasi Birokrasi secara terang mengatakan bahwa reformasi birokrasi adalah strategi untuk membangun aparatur negara agar lebih berdayaguna dan berhasil guna dalam mengemban tugas umum pemerintahan dan pembangunan nasional. Selain itu, dengan sangat pesatnya kemajuan ilmu pengetahuan, teknologi informasi dan komunikasi, serta perubahan lingkungan strategis menuntut birokrasi pemerintahan untuk direformasi dan disesuaikan dengan dinamika tuntutan masyarakat. Berbicara mengenai pengelolaan SDM aparatur memang tidak ada habisnya dan menuntut suatu pemikiran yang mendalam. Hal ini dikarenakan SDM aparatur adalah dimensi dinamis dan unik dibanding mengelola resources yang lain. Manusia memiliki sifat, karakter, motivasi, dan emosi yang berbeda-beda sehingga membutuhkan penanganan/ manage yang berbeda pula untuk setiap personalnya [3].

Pengelolaan SDM aparatur yang optimal akan menyeimbangkan kebutuhan aparatur dan tuntutan organisasi atas aparatur tersebut sehingga terwujudlah peningkatan kinerja dan eksistensi organisasi tersebut. Menurut Notoatmodjo, tujuan utama dari manajemen kepegawaian sebenarnya adalah untuk meningkatkan kontribusi SDM terhadap organisasi dalam rangka mencapai 
produktivitas organisasi tersebut. Yang jika dijabarkan kedalam tujuan yang lebih operasional yaitu [4] :

1. Tujuan masyarakat (societal objective) Untuk bertanggung jawab secara sosial dalam hal kebutuhan dan tantangantantangan yang timbul dari masyarakat. Suatu organisasi yang berada ditengahtengah masyarakat diharapkan membawa manfaat atau keuntungan bagi masyarakat. Oleh karena itu suatu organisasi mempunyai tanggung jawab dalam mengelola sumberdaya manusianya agar tidak mempunyai dampak negatif terhadap masyarakat

2. Tujuan organisasi (organization objective) Untuk mengenal bahwa manajemen sumberdaya manusia itu ada (exist), perlu memberikan kontribusi terhadap pendayagunaan organisasi secara keseluruhan. MSDM bukanlah suatu tujuan dan akhir suatu proses, melainkan suatu perangkat atau alat untuk membantu tercapainya suatu tujuan organisasi secara keseluruhan. Oleh sebab itu, suatu unit atau bagian MSDM disuatu organisasi diadakan untuk melayani bagian-bagian lain organisasi tersebut.

3. Tujuan fungsi (functional objective) Untuk memelihara (maintain) kontribusi bagian-bagian lain agar mereka (SDM dalam tiap bagian) melaksanakan tugasnya secara optimal. Dengan kata lain setiap SDM dalam organisasi itu menjalankan fungsinya dengan baik.

4. Tujuan personel (personel objective) Untuk membantu pegawai dalam mencapai tujuan-tujuan pribadinya, dalam rangka pencapaian tujuan organisasinya. Tujuan-tujuan pribadi karyawan seharusnya dipenuhi,

Untuk mewujudkan harapan-harapan tersebut, maka dibutuhkan unsur aparatur penyelenggaran pemerintahan desa dan kelurahan (pemerintah desa dan badan permusyawaratan desa) yang memiliki kemampuan dalam menyelenggarakan administrasi desa secara tertib. Kegiatan pengabdian bertujuan untuk memberdayakan dan meningkatkan keterampilan aparatur dan masyarakat desa tentang administrasi pemerintahan desa, meningkatkan pengetahuan aparatur dan masyarakat desa dengan fokus pada laporan keuangan desa, dan mendorong tertib administrasi pelayanan desa.

\section{Permasalahan Mitra}

Mengingat kompleksnya permasalahan tersebut di atas dan disadari bahwa tidak semua permasalahan dapat diselesaikan sekaligus dalam kurun waktu tertentu maka berdasarkan justifikasi dan kesepakatan bersama dengan pemerintah maka dipilih beberapa permasalahan prioritas yang harus diatasi yaitu:

1. Masih rendahnya pengetahuan dan pemahaman aparatur pemerintah 
mitra tentang sistem administrasi pemerintahn.

2. Model-model buku administrasi belum tersedia secara lengkap.

3. Berbagai kegiatan pemerintahan belum teradministrasi secara rapih, tertib dan lengkap.

4. Kemampuan aparatur dalam pengelolaan administrasi pemerintahan yang masih rendah.

\section{TARGET DAN LUARAN}

\section{Luaran Dan Target Capaian}

Luaran dalam kegiatan PKM ini ditargetkan adalah sebagai berikut:

1. Menghasilkan model buku administrasi yang meliputi:

a. Buku Administrasi Umum (Model A1 s.d. A8)

b. Buku Administrasi Penduduk (Model B1 s.d. B4)

c. Buku Administrasi Pembangunan (Model D1 s.d. D4)

d. Buku Administrasi Lainnya (Model F1 s.d. F3)

e. Menghasilkan model buku administrasi yang siap diisi oleh aparatur desa.

f. Melakukan pendampingan dan pelatihan tata cara pengelolaan administrasi secara rapih, teratur dan tertib .

g. Laporan kegiatan dan artikel untuk dipublikasikan dalam Jurnal Nasional h. Perbaikan administrasi Mitra binaan.

i. Perbaikan administrasi Mitra binaan.

j. Publikasi Ilmiah di Jurnal/ Prosiding.

\section{Solusi yang ditawarkan}

Solusi yang ditawarkan untuk memecahkan permasalahan yang dihadapi adalah Pembinaan Kapasitas Aparatur dalam Pengelolaan Administrasi. Melalui kegiatan ini aparatur diberikan pengetahuan tentang pentingnya penatausahaan administrasi dan pengetahuan teknis tentang model-model buku administrasi. Selain itu dilakukan pula pendampingan kepada aparatur dalam mengaplikasikan model-model buku administrasi.

\section{METODE PELAKSANAAN}

Metode Pendekatan yang Ditawarkan untuk Mendukung Realisasi Program PKM

\section{Gambaran dan Solusi Terhadap Permasalahan}

Bertolak dari permasalahan aparatur desa pada kedua desa mitra untuk menjawab permasalahan pertama; kurangnya pengetahuan dan kemampuan aparatur desa dalam penegelolaan administrasi desa, maka akan diberikan pelatihan tentang pentingnya administrasi desa yang sangat bermanfaat sebagai sumber informasi dalam perencanaan, pengambilan keputusan, 
pelaksanaan, pengawasan dan evaluasi program pembangunan, pemerintahan, kemasyarakatan dan pemberdayaan masyarakat desa. Solusi yang tepat untuk masalah ini adalah dengan memberikan pengetahuan yang benar bagaimana mengelola administrasi secara rapih teratur dan tertib. Permasalahan kedua, belum tertatanya administrasi pemerintahan desa pada kedua desa mitra yang disebabkan kurangnya pengetahuan dan pemahaman teknis serta belum tersedianya modelmodel buku administrasi desa secara lengkap, maka akan disediakan modul yang berisi model-model buku administrasi desa serta diberikan pelatihan dan pendampingan pada aparatur desa cara pengisian model-model buku administrasi desa. Untuk meningkatkan motivasi aparatur desa dalam mengelola administrasi desa secara lengkap, rapih, teratur dan tertib, maka aparatur desa pada kedua desa mitra akan didampingi oleh dosen dalam arti akan dibimbing untuk mengisi dan mengelola administrasi desa dengan baik.

\section{Gambaran Metode Pendekatan}

Secara metodologis pelaksanaan kegiatan PKM ini dirancang dan akan dilaksanakan melalui penyuluhan, pelatihan dan pendampingan, uji coba, monitoring dan evaluasi yang dirancang dalam selama 1 (satu) bulan yang meliputi empat tahapan kegiatan:

Tahap I rancangan kegiatan: a. Pelatihan kapasitas untuk kegiatan yang dipilih.

b. $\quad$ Mendampingi 2 desa mitra yang dipilih sebagai daerah sasaran kegiatan

c. Membuat modul pelatihan (model buku administrasi desa)

d. Mengaplikan modul pelatihan pada desa sasaran.

Tahap II dengan rancangan kegiatan:

a. Memberikan penyuluhan tentang esensi administrasi pemerintahan desa

b. Memperkenalkan model-model buku administrasi desa

Tahap III dengan rancangan kegiatan:

a. Melakukan pendampingan aparatur desa pada desa mitra

b. Mengaplikasikan (uji coba) modelmodel buku administrasi desa pada desa mitra

Tahap IV dengan rancangan kegiatan:

a. Melakukan monitoring tentang aplikasi model buku administrasi desa

a. Melakukan evaluasi kegiatan.

\section{Rencana Kegiatan/Langkah-langkah}

Solusi Atas Persoal $\neg a n$ yang Disepakati

Bersama,

Persiapan.

Langkah persiapan yang akan dilakukan oleh pelaksana PKM adalah melakukan persiapan yang didahului dengan pembahasan program dan langkah-langkah kerja sampai dengan persiapan administrasi 
dan perangkat pendukung. Kegiatan lain yang masuk dalam persiapan adalah melakukan koordinasi dengan kedua pemerintah desa mitra menyampaikan rencana pelaksanaan kegiatan PKM . Selain itu melakukan koordinasi dengan pemerintah Kecamatan Bolaang Timur untuk menyampaikan program dan persiapan kegiatan.

Persiapan lainnya adalah menyusun instrumen yang akan digunakan untuk menjaring informasi tentang permasalahan mendasar kedua desa mitra. Instrumen yang disusun dimaksudkan untuk mengidentifikasi permasalahan mendasar yang harus dipahami sebelum mengawali kegiatan ini dengan mengidentifikasi dan mempertajam serta menganalisis kembali faktor-faktor penyebab kedua permasalahan pokok di atas. Hasil identifikasi tersebut di samping menjadi dasar penyusunan rencana kerja sekaligus sebagai landasan pelaksanaan kegiatan PKM Langkah persiapan yang lainnya adalah menyusun draf modul bahan ajar/latih yang memuat tentang model buku administrasi desa yang akan dijadikan sebagai bahan acuan untuk diaplikasikan dan digunakan dalam pelaksanaan kegiatan PKM

\section{Pelaksanaan Kegiatan Sosialisasi.}

Langkah pertama yang akan dilakukan dalam proses pelaksanaan kegiatan adalah mengkomunikasikan sebagai upaya untuk mensosialisasikan maksud dan tujuan kegiatan ini kepada kedua pemerintah desa mitra. Kegiatan sosialisasi ini dijadikan sebagai salah satu tahapan penting dalam menyampaikan hal-hal yang berhubungan dengan kegiatan PKM. Kegiatan sosialisasi lebih difokuskan pada pemberian informasi dan pemahaman tentang pentingnya kegiatan yang akan dilaksanakan ini berkaitan dengan peningkatan kemampuan aparatur desa dalam penatausahaan administrasi desa. Kegiatan tersebut menyangkut transformasi gambaran ilmu pengetahuan dan teknologi dalam upaya memecahkan masalah yang dihadapi aparatur desa.

\section{Proses Pembelajaran (Teori)}

Tahapan selanjutnya setelah sosialisasi adalah pelaksanaan kegiatan yang akan ditindaklanjuti dengan kegiatan proses pembelajaran berupa penyuluhan dan pendampingan dalam kegiatan praktek atau implementasi ilmu pengetahuan dan teknologi terhadap aparatur desa yang menjadi kelompok sasaran kegiatan ini. Materi yang akan diajarkan meliputi teori dan praktik. Metode pembelajaran adalah menggunakan metode ceramah, diskusi,pendampingan dan praktek. Berbagai alat bantu ajar yan g akan digunakan untuk mempercepat proses pembelajaran berupa modul dan LCD. Bertolak dari dua permasalahan utama yang akan ditanggulangi bersama adalah:

(1) Informasi umum tentang Desa berdasarkan Undang-Undang Nomor: 6 Tahun 2014.

(2) Pengetahuan umum tentang administrasi pemerintahan desa. Dalam kegiatan ini akan diberikan pengetahuan 
tentang metodologi penelitian khususnya enelitian Tindakan Kelas, beserta contoh topik masalah yang perlu diteliti. Sekaligus juga akan diberikan contoh-contoh proposal dan laporan penelitian. Pelatihan ini disertai dengan praktek agar supaya guru langsung dapat menyusun sebuah proposal penelitian sesuai dengan mata pelajaran yang menjadi tanggung jawabnya.

(3) Pengetahuan tentang model buku administrasi desa. Dalam kegiatan ini aparatur desa akan diberikan pengetahuan bagaimana menata usahakan administrasi desa secara lengkap rapih dan tertib.

\section{Implementasi Model Administrasi Desa}

Implementasi pengetahuan tentang berbagai model administrasi desa merupakan rangkaian kegiatan mewujudnyatakan pengetahuan yang telah diperoleh sehingga memberi dampak yang bermanfaat. Proses implementasi model administrasi desa merupakan salah satu kunci untuk menjawab permasalahan yang dihadapi oleh desa mitra. Dalam mengimplementasikan model-model-model administrasi desa yang ditawarkan, maka akan dilakukan pendampingan dan monitoring terhadap aparatur desa dalam mengaplikasikannya.

\section{Pemantapan Program Kerja dan Evaluasi}

Tahapan pemantapan program kerja dan evaluasi merupakan tindakan yang didasarkan pada hasil evaluasi pada setiap tahapan program kegiatan yang telah dilakukann. Untuk memantau kemajuan program kerja, dilakukan dengan cara mengevaluasi secara langsung aktivitas kerja aparatur desa mitra sejak pengenalan, sampai pada implementasi. Aspek yang dievaluasi mencakup respons, tindakan nyata melalui perilaku kerja setiap apatur serta penguasaan pengetahuan (teori dan praktek) yang dirumuskan dalam dua kriteria keberhasilan yaitu berdasarkan output, outcome atau dampak dari pelaksanaan program PKM. Dalam pelaksanaan kegiatan ini diharapkan dapat mencapai tingkat keberhasilan. Untuk mencapai sasaran tersebut maka proses evaluasi tersebut akan dilakukan sebanyak tiga kali (sebelum, semesntara proses, dan akhir) dengan alasan agar jika belum mencapai tingkat keberhasilan maka perlu memperbaiki atau melengkapi hal-hal yang dianggap menjadi faktor penyebab kegagalan atau kekurangberhasilan kegiatan tersebut.

Kriteria atau indikator berdasarkan output kegiatan PKM dalam rangka memecahkan masalah mitra diukur berdasarkan :

a. Terlaksananya proses fasilitasi, adanya peningkatan kemampuan sumberdaya manusia tentang administrasi pemerintahan desa

b. Termotivasinya aparatur desa dalam melaksanakan administrasi pemerintahan desa secara lengkap, rapih dan tertib.

c. Terciptanya aparatur desa yang memiliki kemampuan dan ketrampilan dalam menatausahakan administrasi pemerintahan desa.

Kriteria keberhasilan berdasarkan outcome atau dampak kegiatan PKM ditentukan berdasarkan adanya

a. Peningkatan kapasitas dan kemampuan aparatur desa mitra dalam menyelesaikan masalah yang dihadapi desa mitra.

b. Peningkatan kemampuan untuk menatausahakan administrasi desa secara lengkap rapid an tertib. 
c. Terciptanya budaya tertib administrasi di kalangan aparatur desa mitra.

\section{HASIL DAN PEMBAHASAN}

Tahap Awal (Survey dan Analisis Situasi Sosial)

Pada tahap ini kegiatan survey dan analisis situasi dilakukan dengan melibatkan beberapa warga desa dengan tujuan untuk melakukan identifikasi potensi dan permasalahan yaitu aspek kelembagaan desa, aspek manajemen pelayanan aparatur desa, aspek transparansi penggunaan dan pelaporan keuangan desa, aspek pembangunan desa, aspek kesehatan, aspek infrastruktur (fasilitas umum dan fasilitas sosial desa) dan aspek kebijakan pemerintahan desa. Kegiatan difokuskan terhadap sejumlah wilayah dan melakukan wawancara terhadap jumlah kepala keluarga. Hasil survey selanjutnya diolah dengan membuat matrik hasil survey dan wawancara.

Tahap Inti (Kegiatan Pendampingan)

Pada tahap ini, kegiatan yang dilakukan adalah :

a) Sosialisasi program;

Sosialisasi pada masyarakat diberikan terkait dengan program yang akan dilaksanakan. Kegiatan dilaksankan di Kantor desa dengan dihadiri oleh masyarakat. Pada tahap ini, tim pengabdian masyarakat bersama-sama mahasiswa melakukan sosialisasi program pelatihan administrasi pemerintahan desa dan pelatihan tata kelola laporan keuangan desa yang akan dilaksanakan di Kelurahan Matani Dua Kota Tomohon selama satu minggu sekali selama satu bulan.

b) Pendampingan pelatihan Administrasi
Pemerintahan desa;

Kegiatan pendampingan diikuti oleh aparatur pemerintahan desa dan masyarakat. Materi-materi yang diberikan dalam kegiatan pendampingan ini adalah tentang buku peraturan desa, buku keputusan kepala desa, buku inventaris dan kekayaan desa, buku aparatur pemerintahan desa, buku tanah kas desa, buku agenda, buku agenda, buku lembaran desa dan berita desa. Kegiatan yang dilaksanakan pada tanggal 12 sampai dengan 13 Agustus 2017 ini diikuti oleh seluruh aparatur pemerintahan desa yang berjumlah 9 (sembilan) orang dan 10 (sepuluh) orang dari perwakilan masyarakat. Kegiatan yang dilaksanakan selama 2 (dua) hari tersebut diberikan pengenalan teori dan praktek penyusunan bukubuku administrasi pemerintahan desa. Dan untuk mengetahui bagaimana tingkat keberhasilan pencapaian kegiatan pendampingan dilakukan evaluasi melalui indikator tahapan perubahan perilaku pengetahuan, sikap dan keterampilan

c) Pendampingan pelatihan Tata Kelola Keuangan Desa.

Pada kegiatan pendampingan ini, masyarakat difokuskan untuk dapat mempraktekkan dan menyusun laporan pertanggungjawaban Anggaran Pendapatan dan Belanja Desa (APBDes). Output yang diharapkan adalah masyarakat terutama aparatur pemerintahan desa mampu menyusun dan menyampaikan laporan atas pelaksanaan tugas, kewenangan, hak, dan kewajibannya dalam pengelolaan keuangan desa. Laporan tersebut bersifat periodik yaitu semesteran dan tahunan, yang disampaikan ke bupati/walikota dan ke Badan Permusyawaratan Desa (BPD). Laporan dimaksud terdiri dari: 1) laporan realisasi pelaksanaan APBDesa; 2) laporan pertanggungjawaban realisasi pelaksanaan 
APBDesa kepada bupati/walikota setiap akhir tahun anggaran; 3) laporan realisasi penggunaan dana desa.

Tahap akhir (Kegiatan pendampingan)

Ada dua kegiatan dalam tahap ini yaitu pendampingan penyusunan buku administrasi pemerintahan desa dan laporan keuangan desa. Pada tahap ini, aparatur pemerintahan desa dan masyarakat bersama-sama menyusun dan mempraktekan hasil pelatihan bersamasama tim pengabdian masyarakat. Kegiatan yang dilaksanakan selama 2 (dua) hari $\mathrm{t}$ sekaligus sebagai tahap evaluasi untuk memantau dan menilai sejauhmana masyarakat dapat mempraktekkan hasil pelatihan yang telah diberikan.

Hasil/Luaran yang Dicapai

Sesuai solusi dan target luaran dalam kegiatan PKM ini ditargetkan, maka kegiatan ini telah menghasilkan model-model buku administrasi desa yang meliputi:

1. Buku Administrasi Umum

2. Buku Administrasi Penduduk

3. Buku Administrasi Keuangan Desa

4. Buku Administrasi Pembangunan

5. Buku Administrasi Badan Permusyawaratan Desa.

\section{KESIMPULAN}

Dari kegiatan yang telah dilaksanakan, dapat disimpulkan beberapa hal yaitu Aparatur Pemerintahan Desa dan masyarakat
Kelurahan Matani Dua Kota Tomohon sebagai mitra pengabdian masyarakat memiliki respon dan antusias yang sangat besar terutama dalam proses pelatihan walaupun dengan segala keterbatasan yang dimiliki. Kegiatan pengabdian masyarakat masyarakat antara tim pengabdian bersama-sama masyarakat di Kelurahan Matani Dua Kota Tomohon melalui kegiatan pelatihan administrasi pemerintahan desa kelurahan dan laporan keuangan berjalan sesuai dengan rencana dan target yang telah ditetapkan.

\section{REFERENSI}

[1] Sururi, A., \& Mulyasih, R. (2017). Pemberdayaan Masyarakat melalui Inovasi Perencanaan Pembangunan berbasis 4R (Rembug, Rencana, Realisasi dan Rawat) di Desa Cilangkap Kecamatan Wanasalam sebagai Pilar Utama Kebijakan Partisipatif dan Gotong Royong. ENGAGEMENT, 1(2), 218-238.

[2] Lembaga Administrasi Negara. 2009. Peningkatan Kapasitas Aparatur Desa.Pusat Kajian Kinerja Otonomi Daerah : Jakarta.

[3] PER/ 15/ M.PAN/ 7/ 2008 Tentang Pedoman Umum Reformasi Birokrasi

[4] Notoatmodjo, Soekidjo. 2003. Pendidikan Dan Perilaku Kesehatan. Rineka. Cipta. Jakarta. 